\title{
Evaluation of photosynthetic photon flux in lettuce cultivation at different shading levels
}

\author{
Nilton Nélio Cometti ${ }^{1} \mathbb{D}$; Josimar V da Silva ${ }^{2} \mathbb{D}$; Everaldo Zonta ${ }^{3} \mathbb{D}$; Raphael MA Cessa ${ }^{4} \mathbb{D}$
}

${ }^{1}$ Instituto Federal de Brasília (IFB), Campus Planaltina, Brasília-DF, Brasil; nilton.cometti@gmail.com; ${ }^{2}$ Instituto Federal de Brasília (IFB), Campus São Sebastião, Brasília-DF, Brasil; josimar.silva@ifb.edu.br; ${ }^{3}$ Universidade Federal Rural do Rio de Janeiro (UFRRJ), SeropédicaRJ, Brasil; ezonta@ufrrj.br; ${ }^{4}$ Instituto Federal de Brasília (IFB), Campus Planaltina, Brasília-DF, Brasil; raphael.cessa@ifb.edu.br

\begin{abstract}
Protected cultivation has grown in Brazil. Generally, greenhouses are covered with transparent plastic film and shading screen. The plastic, over time, loses its transparency due to pollution residues, dust and other debris. The loss of transparency reduces lightness, photosynthesis and leads to losses of productivity and product quality. The losses are not always detectable by the farmer. Additionally, internal shading screens are used to reduce heating transmission to the ground. The objective of this study was to evaluate the impact of shading on lettuce crop productivity and to determine the optimum shading to reach the highest productivity. Plots were set up inside and outside the greenhouse, with four shading levels with black screens $(0,35,50$ and $75 \%)$. The treatments were converted to real shading from the photosynthetic photon flux measurement. The results of fresh and dry phytomass were treated and analyzed by regression as a function of the real shading. In ambient conditions of photosynthetic photon fluxes around $1000 \mu \mathrm{mol} \mathrm{m} \mathrm{m}^{-2} \mathrm{~s}^{-1}$, reaching up to $2000 \mu \mathrm{mol} \mathrm{m}$ $\mathrm{s}^{-1}$ at some hours of the day, typical of tropical environment, lettuce may support a shading of up to $50 \%$ without risk of productivity reduction; under these conditions, shading between 20 and $35 \%$ is beneficial, and can guarantee its maximum productivity in lettuce cultivation. It is recommended that the lettuce producer in protected cultivation monitors the shelf life of the plastic, avoiding that the shading exceeds $50 \%$. In order to compare shading experiments, one should use the incident photon flux (FFI) for the whole crop cycle, indicating the minimum limit value of FFI $=600 \mathrm{~mol} \mathrm{~m}^{-2} \mathrm{cycle}^{-1}$ for the crispy lettuce at an average temperature close to $21^{\circ} \mathrm{C}$.
\end{abstract}

Keywords: Lactuca sativa, plastic film, crop protection, light.

\section{RESUMO}

Avaliação do fluxo de fótons fotossintéticos no cultivo de alface em diferentes níveis de sombreamento

O cultivo protegido tem crescido no Brasil. Geralmente, as estufas utilizam plástico transparente e tela de sombreamento na cobertura. A cobertura de plástico, com o passar do tempo, perde a transparência por adquirir resíduos de poluição, poeira e outros detritos. A perda de transparência reduz a luminosidade, a fotossíntese e acarreta a perda de produtividade e de qualidade dos produtos. O objetivo do trabalho foi estudar o impacto do sombreamento sobre a produtividade da cultura da alface e determinar o sombreamento ótimo para alcançar o máximo de produtividade. Foram montadas parcelas dentro e fora da estufa, com quatro sombreamentos com telas pretas $(0,35,50 \mathrm{e}$ $75 \%$ ). Os tratamentos foram convertidos em sombreamento real a partir da medição de fluxo de fótons fotossintéticos transmitidos. Os resultados de fitomassa fresca e seca foram tratados e analisados por regressão em função do sombreamento medido. Em condições ambientais de fluxo de fótons fotossintéticos em torno de $1000 \mu \mathrm{mol}$ $\mathrm{m}^{-2} \mathrm{~s}^{-1}$, alcançando até $2000 \mu \mathrm{mol} \mathrm{m} \mathrm{m}^{-2} \mathrm{~s}^{-1}$ em algumas horas do dia, típico de ambiente tropical, a cultura da alface pode suportar um sombreamento de até $50 \%$ sem risco de redução da produtividade. Sombreamentos entre 20 e 35\%, nessas condições, são benéficos, podendo garantir o máximo de sua produtividade. Recomenda-se ao produtor de alface em cultivo protegido monitorar a vida útil do plástico, evitando que o sombreamento ultrapasse $50 \%$. Para fins de comparação entre experimentos com sombreamento, propõe-se que seja utilizado o fluxo de fótons incidentes (FFI) para todo o ciclo da cultura, indicando o valor limite mínimo de FFI $=600 \mathrm{~mol} \mathrm{~m}^{-2}$ ciclo $^{-1}$ para a alface crespa em temperatura média próxima a $21^{\circ} \mathrm{C}$.

Palavras-chave: Lactuca sativa, filme plástico, cultivo protegido, luminosidade.

\section{Received on May 6, 2019; accepted on February 22, 2020}

$\mathrm{M}$ uch of Brazil's vegetable production comes from protected cultivation, which grows rapidly. The crop production is directly related to the photosynthetic activity and, consequently, to the accumulation of photoassimilates. However, when solar radiation is excessively high, there is an increase in the transpiratory rate of the plant, causing stomatal closure and reduction of photosynthesis (PoljakoffMayber \& Gale, 2012). In addition, photorespiration can increase, thus reducing liquid photosynthesis (Taiz \& Zeiger, 2013). Greenhouses are generally covered with transparent plastic film and shading screen. The plastic film loses its transparency over time due to pollution 
residues, dust and other debris, and deteriorates with sunlight exposure. The loss of transparency reduces lightness, photosynthesis and leads to losses of productivity and product quality, increasing economic losses. These losses are not always detectable by the farmer. In addition to the use of clear plastic for crop protection, shading screens are commonly used to reduce irradiance and temperature within the greenhouses, thus increasing the productivity of the protected crops (Santosh et al., 2017; Lemos Neto et al., 2017). Costa et al. (2011) did not observe significant differences in the arugula productivity in treatments with shading up to $40 \%$, but there was an improvement in productivity with shading of $50 \%$. Seabra et al. (2009) found similar data for lettuce in tropical environment with high temperatures. In this case, the productivity was higher when shading was close to $50 \%$, and crops were favored with a specific type of reflective screen, which also promoted the reduction of temperature by 10 to $20 \%$. Bezerra Neto et al. (2005) showed that the use of a polypropylene screen reduces the direct incidence of solar rays, increasing the photosynthesis and reducing lettuce respiration due to the favorable conditions, which increased accumulated dry matter.

On one hand, the fact that the farmer does not have scientific knowledge on the subject makes him unaware that shading can be at an excessive level; this way, he does not know the occasion to change the greenhouse plastic cover. By the other hand, he does not have simple and cheap mechanisms to make the decision to change the greenhouse cover safely. This decision is usually subjective, due to common sense, and can be both early and late, both leading to economic losses. In order to avoid further losses in productivity, the plastic cover is replaced every two years, but it can also cause financial loss by the early replacing, because the plastic could still have some useful time.

In addition to the effect of light on growth, it is critical to consider the temperature that significantly affects growth (Frantz et al., 2004). The thermal accumulation, consolidated in the
Degrees-Day concept, is the simplest means of productivity comparability as a function of the difference between the average temperature and the basal temperature of the crop, below which the crop stops growing (Araújo et al., 2010).

In order to assist the producer in protected cultivation, our group developed a mobile application, called "Estufa Inteligente" which allows, with relative precision, to determine the percentage of greenhouse shading indicating whether it is still suitable for the crop (Silva \& Cometti, 2017). In this case, one should know the ideal shading pattern for the crop as well as the shading limit so that there is no loss of productivity in order to properly feed data into the application.

The objective of this study was to evaluate the impact of shading on lettuce crop productivity and to determine the optimum shade for maximum productivity.

\section{MATERIAL AND METHODS}

A research was carried out at Campus Planaltina, Instituto Federal de Brasilia, Distrito Federal, Brazil (15'39'24'S, 4741'50"W, $969 \mathrm{~m}$ altitude). The tropical climate with dry winter and climate classification is Aw according to Köppen, and the average temperature is $21.1^{\circ} \mathrm{C}$.

The research was set during the period of April to May 2017 with crisp lettuce cultivar Wanda. Two beds containing the plots were cultivated, one inside and other outside the greenhouse. Both were conducted under the same conditions of irrigation, fertilization and cultural treatment.

The experimental design, in blocks, had two environments, inside and outside the greenhouse, four shading levels $(0$, 35,50 and $75 \%$ ) and three replications. Each plot was composed of $1.0 \mathrm{~m}^{2}$, with 16 plants spaced $25 \times 25 \mathrm{~cm}$. Only the four central plants of the bed were collected for the phytomass measurement. The others were discarded as border. The shading was done with plastic screens of different meshes, placed on supports at $0.7 \mathrm{~m}$ from the ground covering the entire treatment portion, both inside and outside the greenhouse. The greenhouse, three meters high, was covered with transparent plastic with anti-UV additive, $100 \mu \mathrm{m}$ thick, and three years old. In order to avoid differences in temperatures within treatments, the protective screen was removed on the sides of the greenhouse. The average temperature observed in the treatments was $21^{\circ} \mathrm{C}$ with a maximum variation of $1^{\circ} \mathrm{C}$ between treatments accompanied by a set of DS18B20 sensors connected in a datalogger built with Arduino MEGA 2560 board (Arduino, 2017).

After the transplanting of the seedlings, the photosynthetic photon flux (PPF) measurement was made three times a day, close to 9:00 a.m., 12:00 a.m. and 15:00 p.m., always recording PPF, date, and time. We used a portable radiometer QMSW brand Apogee Instruments ${ }^{\circledR}$ for these measurements. The PPF readings were adjusted in quadratic curves. These curves were integrated to total the mol volume of photons incident in the experiment for a period of 60 days for 12 hours a day.

The plants were collected 35 days after transplanting when the plots with larger plants were ready for commercialization. At harvest, the plants were weighed into the fresh phytomass and taken to the dehydrator to measure the dry mass.

The calculation of the thermal sum, in degrees day, was made based in equation 1 :

$\mathrm{DD}=\sum_{i=1}^{n}$ Taveg $-\mathrm{Tb}$

where $\mathrm{DD}=$ cumulative day degree; Taveg $=$ average air temperature $\left({ }^{\circ} \mathrm{C}\right)$; and $T b=$ base temperature, which for this experiment were considered $10.0^{\circ} \mathrm{C}$, and $\mathrm{n}=$ number of days at harvest (Araújo et al., 2010).

Data were analyzed on Microsoft Office Excel and plotted in charts on Sigmaplot ${ }^{\circledR}$ in which the regression curves were elaborated.

\section{RESULTS AND DISCUSSION}

The treatments used in the experiment with photosynthetic photon fluxes (PPF) are shown in Figure 1 (A). The error bars have large amplitude, especially in 
treatments with lower shading (external cultivation, 0 and $35 \%$ ) because they contain data collected at different times (near 9:00, 12:00 and 15:00). The PPF readings on these moments allowed us to calculate the actual shading as shown in Figure 1B. These actual (measured) shading treatments were used for regression and shading effect analysis. From now on the term shading will be used for the actual (real) shading calculated from the PPF readings.

The PPF readings throughout the day were adjusted in polynomial curves shown in Figure 2, indicating the greater amplitude of the flux of photosynthetic photons throughout the day in the treatments with less or no shading, especially 0 and $35 \%$ in the outside of the greenhouse.

The fresh phytomass production as a function of the PPF reduction by the actual (measured) shading is shown in
Figure $3 \mathrm{~A}$, and the dried phytomass in Figure 3B. In both variables there was a sharp fall up to $60 \%$ of shading, indicating in general terms that the lettuce would not support such shading without loss of productivity. The maximum fresh phytomass production calculated from the second degree polynomial was $186.5 \mathrm{~g} \mathrm{plant}^{-1}$, with $23.6 \%$ shading. Calculating a loss as high as $10 \%$ in fresh phytomass production, $167.8 \mathrm{~g} \mathrm{plant}^{-1}$ would be obtained with $48 \%$ actual shading (dashed line cutting the " $x$ " axis). The maximum dry mass calculated from the second degree polynomial fit was $16.8 \mathrm{~g}$ plant $^{-1}$, with $28 \%$ shading. Assuming a reduction of up to $10 \%$ in dry biomass, $15.1 \mathrm{~g} \mathrm{plant}^{-1}$, would be obtained with $58 \%$ shading. In both variables, fresh and dry biomass, with shading of 48 and $58 \%$, respectively, aiming to guarantee a maximum of $10 \%$ productivity loss,

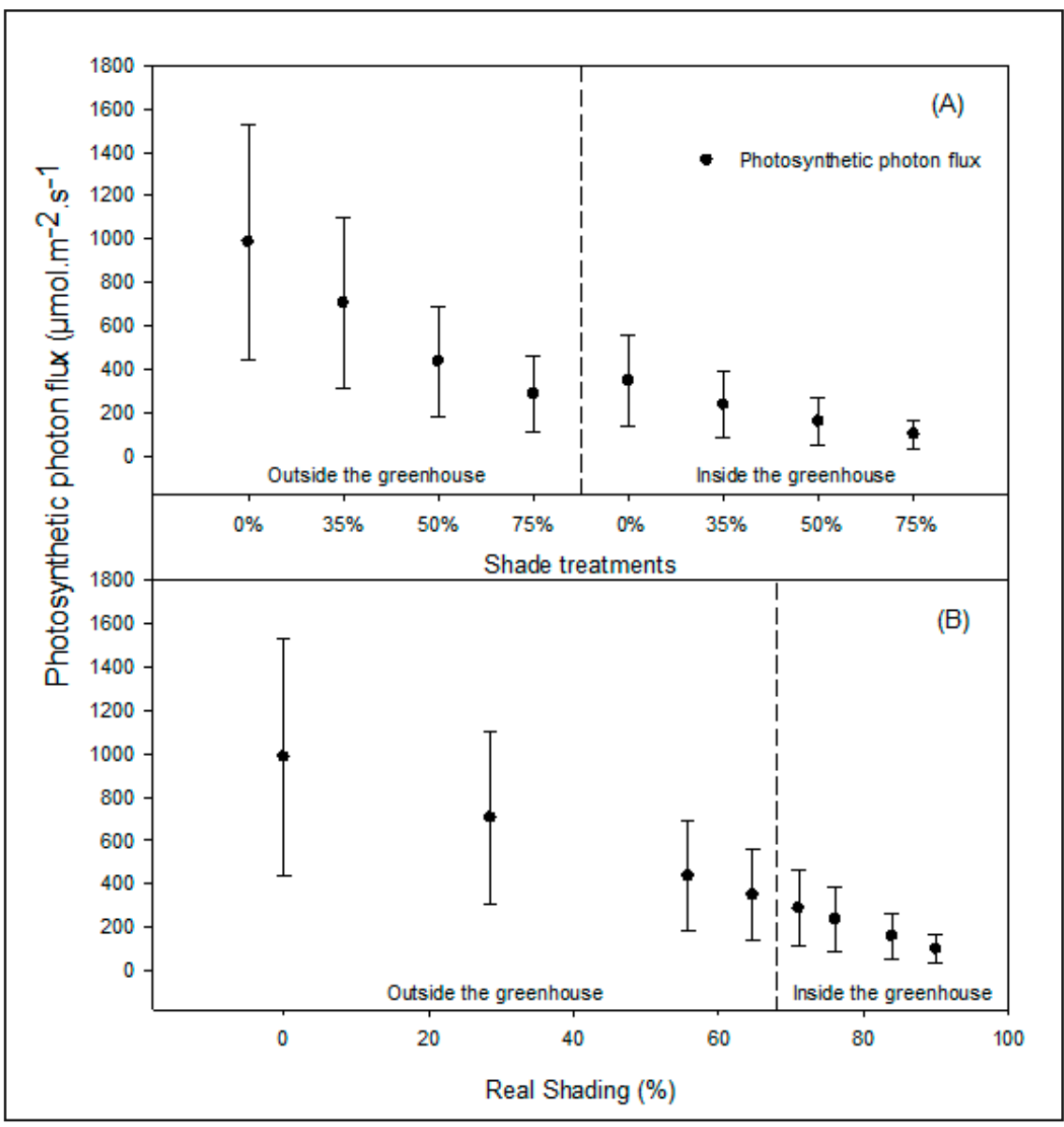

Figure 1. Photosynthetic photon flux (PPF) in different shading levels with black screen. The inside area of the greenhouse had additional shading of the transparent plastic. $A=P P F$ variation as a function of applied treatments; $B=P P F$ variation as a function of measured actual shading. Error bars show PPF measurements throughout the day. Planaltina, IFB, 2017. yields are above the lower limit of the $95 \%$ confidence interval indicated in Figure 3 by the dotted curves.

The obtained data show that there is a great plasticity in the adaptation of lettuce plants to the photosynthetically active radiation. In this experiment, the $0 \%$ treatment (full sunlight), the PPF average was $986 \pm 544 \mu \mathrm{mol} \mathrm{m}{ }^{-2}$ $\mathrm{s}^{-1}$, depending on the time during the day. In treatments with shading, results show that productivity was maintained until the treatment with $50 \%$ of actual shading, ie, $\mathrm{PPF}=436 \pm 255 \mu \mathrm{mol} \mathrm{m}^{-2} \mathrm{~s}^{-1}$ (Figure 1B, treatment $0 \%$ ). Therefore, productivity can be maintained with an average PPF variation of approximately 450 to $1000 \mu \mathrm{mol} \mathrm{m} \mathrm{m}^{-2} \mathrm{~s}^{-1}$. C3 plants, which include lettuce, have a saturated photon acceptor system usually above $500 \mu \mathrm{mol} \mathrm{m}^{-2} \mathrm{~s}^{-1}$, well stated by Taiz $\&$ Zeiger (2013); this explains why there is "surplus" light for plants such as lettuce in the tropical environment. The maximum phytomass productivity reached between 20 and 35\% shading (for fresh and dry phytomass) shown in Figure 3 corroborates the premise of the reduction of liquid photosynthesis in C3 plants subjected to high radiance and high temperature (Mondal et al., 2016), which occurs in a tropical environment in full sunlight as observed in the $0 \%$ shading treatment of this experiment.

Many C3 species are facultative sun plants and adapted to shading, producing morphological and photosynthetic characteristics similar to shaded plants. They reduce their rate of respiration, reduce the photosynthetic rate, and they present saturation of the photosynthesis in low irradiance. These plants develop the ability to grow in the shade, but their growth is slow as can be observed in treatments with shading above $50 \%$. In a study with arugula, Costa et al. (2011) did not observe significant differences in productivity within treatments with shading up to $40 \%$, but favored with shading of $50 \%$. Seabra et al. (2009) found similar data for lettuce on tropical environment under high temperature favoring shade productivity close to $50 \%$ along with a specific type of reflective screen, which promoted the reduction of temperature by 10 to $20 \%$; this demonstrates that there is actually 
surplus light in the tropical environment, and that the use of some shading may even be beneficial. Excessive shading, however, can lead to an abrupt reduction in productivity. In the present study, shading above $60 \%$ caused productivity loss of up to $32 \%$ every $10 \%$ increase in shading. Therefore, one should keep the shading under control so that it does not reach critical levels, in this case, $50 \%$ shading. In our experiment, the greenhouse in which the study was based on (which is similar to those found in the surrounding region) already had a shading of $64 \%$ leading to a reduction of $35 \%$ in phytomass production in relation to the optimum production calculated by the adjustment. This

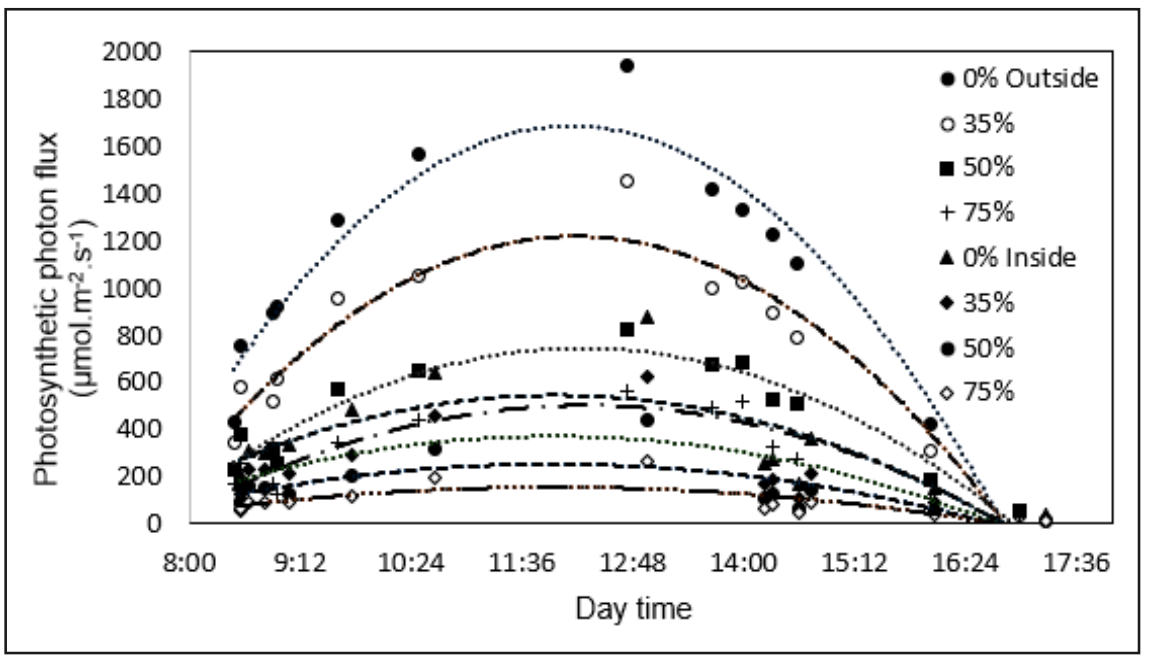

Figure 2. Variation of the photosynthetic photon flux throughout the day in different shading levels with black screen. Planaltina, IFB, 2017.

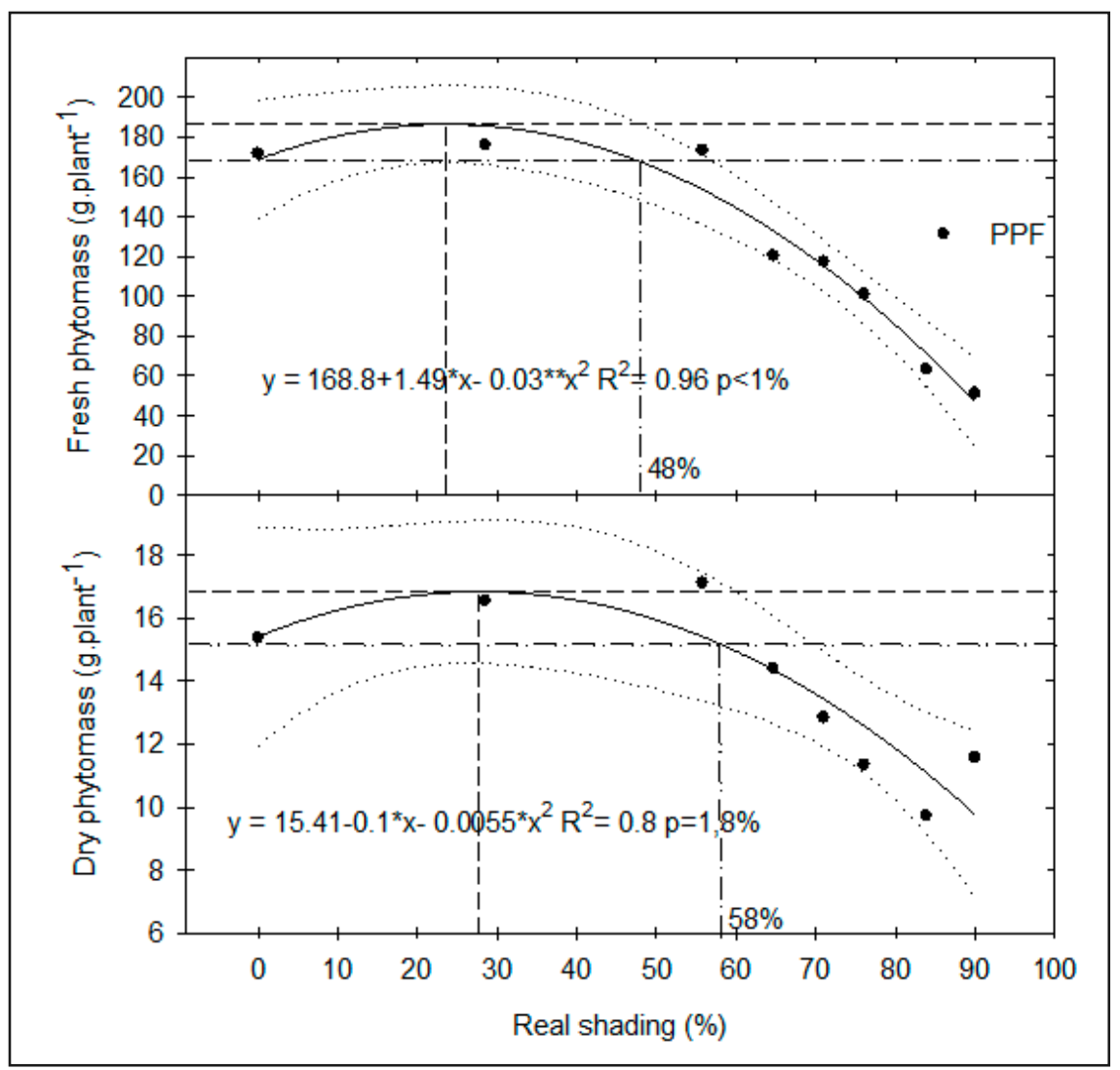

Figure 3. Effect of shading on lettuce phytomass production. Dotted lines indicate $95 \%$ confidence interval. Planaltina, IFB, 2017. reduction is not easily noticeable on the field because it is measurable only with empirical experiments that can make rigid statistical comparisons, which rural producers are not able to do. Even so, monitoring the transparency conditions of the plastic greenhouse cover is critical, and a simple and inexpensive apparatus is required by the producer such as a mobile app that can express the shading of the greenhouse cover.

The correlation between actual shading and incident photosynthetic photons (IPP) throughout the experiment was fit in the first order equation: " $\mathrm{y}=1352-13.7 * \mathrm{x}$ ", with $\mathrm{R}^{2}=0.99 \mathrm{p}<1 \%$. It shows how the incident radiation curves of Figure 2 represent the reality of the incidence of photosynthetically active radiation since its integration returns the volume of incident photons perfectly correlated with real shadings. The integration of the incident photon curve is important to establish the shading utilization methodology in experiments since many results presented may be unfeasible considering the use of apparent shading percentages, which were simply originated from values announced for commercial meshes. A commercial shading screen of $50 \%$ does not necessarily represent an actual shading of $50 \%$; therefore, results such as of Guerra et al. (2017), who found an increase in lettuce productivity in a $50 \%$ shading-screen environment as a result of increased photosynthetic activity, became difficult to be introduced on other environments due to lack of a comparative basis since there is no indication of PPF measurements that allow the identification of the actual shading even if the importance of absolute work results remains preserved.

In order to assist the direct measurement of the shading percentage when there is no photosynthetic photon sensor available, we suggest the use of the light sensor of the cell phone, achieving this way a reasonable accuracy at field level as can be observed in the mobile app "Estufa Inteligente (Smart Greenhouse)"; this app is available at the Google Play ${ }^{\circledR}$ store, developed by scientists of the Instituto Federal de Brasilia (Silva \& Cometti, 2017). 
Table 1. Photosynthetic photon flux (PPF), fresh and dry phytomass, incident photosynthetic photons (IPP), and photosynthetic photon efficiency (PPE) of lettuce as a function of shading with black plastic screen. Planaltina, IFB, 2017.

\begin{tabular}{|c|c|c|c|c|c|c|}
\hline $\begin{array}{l}\text { Actual } \\
\text { shading (\%) }\end{array}$ & 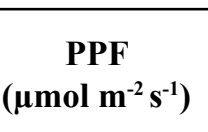 & $\begin{array}{r}\begin{array}{c}\text { Fresh } \\
\text { phytomass }\end{array} \\
\text { (g pla }\end{array}$ & $\begin{array}{l}\begin{array}{c}\text { Dry } \\
\text { phytomass }\end{array} \\
\left.\text { nt }^{-1}\right)\end{array}$ & Curve equation & $\begin{array}{c}\text { IPP } \int_{6}^{18} \\
\left(\mathrm{~mol} \mathrm{~m}^{-2} \text { cycle }^{-1}\right)\end{array}$ & $\begin{array}{c}\text { PPE } \\
\left(g_{\mathrm{ms}} \text { mol photon }^{-1}\right)\end{array}$ \\
\hline 0.0 & $986.0 \pm 544.1$ & $171.5 \pm 25.9$ & $15.4 \pm 1.9$ & $y=-44531 x^{2}+45081 x-9722.9$ & 1352 & 0.18 \\
\hline 28.5 & $705.2 \pm 396.1$ & $175.9 \pm 35.4$ & $16.6 \pm 2.3$ & $y=-32627 x^{2}+33159 x-7206.2$ & 990 & 0.27 \\
\hline 55.8 & $436.0 \pm 255.4$ & $173.3 \pm 52.3$ & $17.1 \pm 4.6$ & $y=-19718 x^{2}+20159 x-4407.7$ & 598 & 0.46 \\
\hline 64.7 & $347.9 \pm 209.6$ & $120.3 \pm 18.8$ & $12.8 \pm 1.9$ & $y=-14036 x^{2}+14387 x-3184.1$ & 425 & 0.54 \\
\hline 71.0 & $286.4 \pm 175.8$ & $117.2 \pm 37.1$ & $14.4 \pm 4.9$ & $y=-13427 x^{2}+13412 x-2804.1$ & 408 & 0.50 \\
\hline 76.1 & $235.7 \pm 150.7$ & $100.9 \pm 1.7$ & $11.3 \pm 1.5$ & $y=-9272.7 x^{2}+9237.5 x-1928.9$ & 280 & 0.65 \\
\hline 83.9 & $158.4 \pm 108.3$ & $63.1 \pm 9.5$ & $9.7 \pm 2.0$ & $y=-6439.7 x^{2}+6415.7 x-1344.6$ & 196 & 0.79 \\
\hline 90.0 & $99.0 \pm 65.6$ & $51.2 \pm 10.2$ & $11.6 \pm 4.1$ & $y=-3893.5 x^{2}+3886.6 x-814.33$ & 118 & 1.56 \\
\hline
\end{tabular}

The average PPF in the full sun was $986.0 \mu \mathrm{mol} \mathrm{m}^{-2} \mathrm{~s}^{-1}$, falling to 99.0 $\mu \mathrm{mol} \mathrm{m} \mathrm{m}^{-2} \mathrm{~s}^{-1}$ with $90 \%$ shading (Table 1). The maximum productivity of fresh phytomass was reached at $753 \mu \mathrm{mol}$ $\mathrm{m}^{-2} \mathrm{~s}^{-1}$ (with 24\% actual shading) and dry mass with $710 \mu \mathrm{mol} \mathrm{m}^{-2} \mathrm{~s}^{-1}$, or $28 \%$ shading. Thus, we have a reference value, between 24 and $28 \%$, for practical purposes of comparison within experiments with shading. The average reading PPF is not always a determining factor since variations of temperature affect the growth of lettuce. Hammer et al. (1978), for example, established the PPF value of $400 \mu \mathrm{mol} \mathrm{m}^{-2} \mathrm{~s}^{-1}$ as the ideal value for lettuce development in the growth chamber while Galon (2012) cultivated the greenhouse lettuce with an average PPF of $523 \mu \mathrm{mol} \mathrm{m} \mathrm{m}^{-2} \mathrm{~s}^{-1}$. Thus, for comparison purposes, using the variable of incident photosynthetic photons (IPP) is preferable since it integrates the total volume of photons susceptible to assimilation by the plant photosynthetic apparatus.

Frantz et al. (2004) cultivated lettuce in a growth chamber with high performance, and high PPF $(800 \mu \mathrm{mol}$ $\mathrm{m}^{-2} \mathrm{~s}^{-1}$ ), with a cycle lasting 28 days until harvest with 16 hours of daily light. By integrating PPF, they had 1,290.0 mol of incident photosynthetic photons per square meter. In the present experiment (60-day cycle), we obtained by integrating the curves of Table 1 , at full sun, 1,352.0 mol of photons $\mathrm{m}^{-2}$ (Table 1 ) which is a very close value to the one obtained by them. However, the presence of photosynthetic photons incident above the saturation point should be emphasized since the productivity optimum calculated in this experiment was around $950 \mathrm{~mol}$ photons. This result demonstrates the importance of determining PPF when treatments are related to shading, allowing this way to make inferences at any location, or latitude. C3 plants usually saturate with PPF in the range between 600 and $800 \mu \mathrm{mol}$ of quanta $\mathrm{m}^{-2}$ $\mathrm{s}^{-1}$ (Vieira et al., 2010). In our study, the lettuce grew satisfactorily up to $55.8 \%$ of actual shading (Figure 3) without compromising productivity, reaching an average $\mathrm{PPF}=436.0 \mu \mathrm{mol} \mathrm{m}^{-2} \mathrm{~s}^{-1}$ (Table 1), or IPP $=598 \mathrm{~mol} \mathrm{~m}^{-2} \mathrm{cycle}^{-1}$ for the crisp lettuce at average temperature close to $21^{\circ} \mathrm{C}$.

The quantum efficiency (QE) in $\mathrm{C} 3$ ranges from $15.4\left(20^{\circ} \mathrm{C}\right)$ to 18.9 mol quanta mol $\mathrm{CO}_{2}^{-1}\left(30^{\circ} \mathrm{C}\right)$ under natural $\mathrm{CO}_{2}$ concentration conditions. Considering that the dry mass of the plants contains about $40 \%$ of $\mathrm{CO}_{2}$ assimilated in the photosynthesis (Lambers, 2006), in this experiment the quantum efficiency with $55 \%$ shading was 240 mol photosynthetic photons $\mathrm{mol} \mathrm{CO}_{2}^{-1}$. This considerable difference in relation to the one proposed by Lamber et al. (2006) probably occurs according to the form of calculation used. In this experiment we opted for the actual calculation of photosynthetic photon efficiency (PPE) (Table 1), which comprises the entire cycle even when most of the photons cannot be assimilated because there is not enough leaf area to cover the entire area. Thus, the PPE with $55 \%$ shading was 0.46 $\mathrm{g} \mathrm{mol}^{-1}$, very close to the maximum value found by Cometti \& Bugbee (2010) for curly lettuce at the growing temperature of $25^{\circ} \mathrm{C}$ during the day and $20^{\circ} \mathrm{C}$ during the night, thereby $0.41 \mathrm{~g}$ $\mathrm{mol}^{-1}$. According to them, below the aforementioned temperatures, $20 / 15^{\circ} \mathrm{C}$ day/night, the PPE drops to $0.2 \mathrm{~g} \mathrm{~mol}^{-1}$. Frantz et al. (2004) found higher values, reaching up to $0.8 \mathrm{~g} \mathrm{~mol}^{-1}$ at temperatures close to $30^{\circ} \mathrm{C}$. However, their studies were carried out with high levels of $\mathrm{CO}_{2}$, which speed up the plant growth. In the present study excessive shading of $90 \%$ turns out to be counterproductive although PPE reached $1.56 \mathrm{~g} \mathrm{~mol}^{-1}$. Thus, shading above $50 \%$, despite the increase of PPE, does not allow sufficient productivity due to absence of photosynthetic photon volume. The PPE stabilizes around $0.5 \mathrm{~g} \mathrm{~mol}^{-1}$ if the shading level is up to $70 \%$; this way it does not make the shading above $50 \%$ to be sufficiently advantageous for productivity gain. Therefore, we suggest the use of this methodology of calculation of the PPE since considering the methodology is fundamental when interpreting results in order not to compromise the comparability within different experimental situations.

In this experiment, plants were collected at 35 days after transplantation, that is, 60 days after sowing. The accumulated degree-days (DD) were 666, with a maximum dry mass production of $16.8 \mathrm{~g} \mathrm{plant}^{-1}$. Araújo et al. (2010) obtained phytomass yields ranging from $8 \mathrm{~g} \mathrm{plant}^{-1}$ with 514 degree-days to $19 \mathrm{~g}$ plant $^{-1}$ with 557 degree-days, that means a large range of productivity as a function of several 
factors besides temperature. Madariaga \& Knott (1951) published a classic onepage article pointing to the inefficiency of the thermal accumulation system for predicting lettuce harvest. Therefore, the accumulation of degree-days cannot be a value analyzed independent of other variables. That's why one should include the incident photosynthetic photons as an important variable.

Concluding, in ambient conditions of photosynthetic photon fluxes around $1000 \mu \mathrm{mol} \mathrm{m} \mathrm{m}^{-2} \mathrm{~s}^{-1}$, reaching up to 2000 $\mu \mathrm{mol} \mathrm{m} \mathrm{m}^{-2} \mathrm{~s}^{-1}$ at some times of the day, typical of tropical environment, lettuce culture can support a shading of up to $50 \%$ without risk of productivity reduction.

Shading between 20 and $35 \%$, under these conditions, is beneficial and can guarantee the maximum productivity to the lettuce crop.

We recommended the lettuce producer of protected crops to monitor the plastic cover lifespan in order to avoid that the shading exceeds $50 \%$ opacity; the producer is also recommended to avoid the use of shading screens in greenhouses with plastic that has already been used for some time and may have signs of dusting and transparency loss.

In order to compare shading experiments, we propose to use the incident photon flux ( $\mathrm{mol} \mathrm{m} \mathrm{m}^{-2}$ cycle $^{-1}$ ) for the whole crop cycle, indicating the minimum limit value of $600 \mathrm{~mol} \mathrm{~m}^{-2}$ cycle $^{-1}$ for curly lettuce at an average temperature close to $21^{\circ} \mathrm{C}$.

\section{AKNOWLEDGEMENTS}

We thank IFB for the financial support, Henio Delfino Ferreira de Oliveira for the calculations; José Luiz
Soares for the technical support, and Evandro de Paula Lima for the text revision.

\section{REFERENCES}

ARAÚJO, TS; FIDELES FILHO, J; KUMAR, KK; RAO, TVR. 2010. Crescimento da alfaceamericana em função dos ambientes, épocas e graus-dias. Revista Brasileira de Ciências Agrárias 5: 441-449.

ARDUINO. 2018. Arduino. Available at https:// www.arduino.cc/. Accessed April 4, 2018.

BEZERRA NETO, F; ROCHA, RCC; NEGREIROS, MZ; ROCHA, RH; QUEIROGA, RCF. 2005. Produtividade de alface em função de condições de sombreamento e temperatura e luminosidade elevadas. Horticultura Brasileira 23: 189-192. DOI:10.1590/S0102-05362005000200005.

COMEtTi, NN; BUGBEE, B. 2010. Produtividade e eficiência fotossintética da alface hidropônica em câmara de crescimento em função do nitrato na solução nutritiva. Horticultura Brasileira 28: 877-884.

COSTA, CMF; SEABRA JÚNIOR, S; ARRUDA, GR; SOUZA, SBS. 2011. Desempenho de cultivares de rúcula sob telas de sombreamento e campo aberto. Semina: Ciências Agrárias 32: 93-102.

FRANTZ, JM; RITCHIE G; COMETTI, NN; ROBINSON, J; BUGBEE, B. 2004. Exploring the limits of crop productivity: beyond the limits of tipburn in lettuce. Journal of the American Society for Horticultural Science 129: 331-338. Available at $<\mathrm{http}: / /$ journal. ashspublications.org/content/129/3/331.full. pdf + html $>$. Accessed July 5, 2017.

GALON, K. 2012. Avaliação do desempenho de cultivares de alface em cultivo hidropônico e panorama da hidroponia no Estado do Espirito Santo. UFES, Alegre. 92p. (M.Sc. Dissertation). Available at $<\mathrm{http}$ ://repositorio. ufes.br/bitstream/10/6540/1/Karla\%20Galon. pdf $>$ Accessed August 4, 2018.

GUERRA, AMN; COSTA, ACM; TAVARES, PRF. 2017. Atividade fotossintética e produtividade de alface cultivada sob sombreamento. Revista Agropecuária Técnica 38: 125-132. DOI: 10.25066/agrotec.v38i3.29246

HAMMER, PA; TIBBITTS, TW; LANGHANS,
RW; MCFARLANE, JC. 1978. Base-line growth studies of 'Grand Rapids' lettuce in controlled environments. Journal of the American Society of Horticultural Science 103: 649-654.

LAMBERS, H; CHAPINIII, FS; PONS, TL. 2006. Plant physiological ecology. New York: Springer, 2006. 540p.

LEMOS NETO, HS; GUIMARÃES, MA; TELLO, JPJ; MESQUITA, RO; VALE, JC; LIMA NETO, BP. 2017. Productive and physiological performance of lettuce cultivars at different planting densities in the Brazilian Semi-arid region. African Journal of Agricultural Research 12: 771-779. DOI: 10.5897/AJAR2016.11961.

MADARIAGA, FJ; KNOTT, JE. 1951. Lettuce growth rates: investigations find heat unit accumulations not a reliable means of predicting harvest time. California Agriculture 5: 4-4.

MONDAL, S; GHOSAL, S; BARUA, R. 2016. Impact of elevated soil and air temperature on plants growth, yield and physiological interaction: a critical review. Scientia Agriculturae 14: 293-305. DOI: 10.15192/ PSCP.SA.2016.14.3.293305

POLJAKOFF-MAYBER, A; GALE, J. 2012. Physiological basis and practical problems of reducing transpiration. In: KOZLOWSKI, TT (ed). Water deficits and plant growth v. 3. Amsterdam: Elsevier. p.277-306.

SANTOSH, DT; TIWARI, KN; SINGH, VK; REDDY, ARG. 2017. Micro climate control in greenhouse. International Journal of Current Microbiological Appied Science 6: 1730-1742. DOI: 10.20546/ijcmas.2017.603.199

SEABRA, S; SOUZA, SBS; THEODORO, VCA; NUNES, MCM; AMORIN, RC; SANTOS, CL; NEVES, LG. 2009. Desempenho de cultivares de alface tipo crespa sob altas temperaturas. Horticultura Brasileira 27: S3171-S3176.

SILVA, JV; COMETTI, NN. 2017. Estufa Inteligente. IFB, Brasília. Available at $<\mathrm{https}$ :// play.google.com/store/apps/details?id=com. thunkable.android.josimarviana.Estufa Inteligente\&hl=en_US $>$. Accessed April 4, 2018.

TAIZ, L; ZEIGER, E. 2013. Fisiologia Vegetal. $5^{\mathrm{a}}$ ed. Porto Alegre: Artmed. 918p.

VIEIRA, LE; SOUZA, GS; SANTO, AR; SILVA, JS. 2010. Manual de fisiologia vegetal. São Luis: EDUFMA. 230p. 